Article

\title{
Antecedents of Purchase Intention at Starbucks in the Context of Covid-19 Pandemic
}

\author{
Jimin Shim ${ }^{1}$, Joonho Moon ${ }^{2} \mathbb{D}$, Myungkeun Song ${ }^{3}$ and Won Seok Lee ${ }^{1, * \mathbb{D}}$ \\ 1 Department of Tourism and Recreation, Kyonggi University, 24, Kyonggidae-ro 9-gil, Seodaemun-gu, \\ Seoul 03753, Korea; shim5515@naver.com \\ 2 Department of Tourism Administration, Kangwon National University, Hyoja2-Dong, Kangwon University \\ Rd, Chooncheon 200-701, Korea; joonhomoon0412@gmail.com \\ 3 Department of Tourism Management, Dong-A University, 225 Gudeok-ro, Seo-gu, Busan 49236, Korea; \\ mkssong83@gmail.com \\ * Correspondence: lws79877@gmail.com
}

Citation: Shim, J.; Moon, J.; Song, M.; Lee, W.S. Antecedents of Purchase Intention at Starbucks in the Context of Covid-19 Pandemic. Sustainability 2021, 13, 1758. https://doi.org/ $10.3390 /$ su13041758

Academic Editors: Andrea Pérez and Kisang Ryu

Received: 12 January 2021

Accepted: 2 February 2021

Published: 6 February 2021

Publisher's Note: MDPI stays neutral with regard to jurisdictional claims in published maps and institutional affiliations.

Copyright: (c) 2021 by the authors. Licensee MDPI, Basel, Switzerland. This article is an open access article distributed under the terms and conditions of the Creative Commons Attribution (CC BY) license (https:/ / creativecommons.org/licenses/by/ $4.0 /)$.

\begin{abstract}
The purpose of this research is to examine the determinants of coffee shop purchase intention. The research domain is Starbucks, which is the brand ranked first in the coffee shop market. This study selects healthiness, hygiene, quarantine, ease of app use, and environmental responsibility as candidates for the antecedents of purchase intention. For hypothesis testing, this research used a survey and recruited survey participants using Amazon Mechanical Turk, and carried out multiple linear regressions to test research hypotheses. The number of valid observations for the data analysis is 474 . It was found that purchase intention is positively influenced by healthiness, hygiene, quarantine, and ease of app use. However, environmental responsibility was identified as a nonsignificant attribute to account for purchase intention. Practical implications are presented for coffee shop management. The outcomes contribute to the literature by scrutinizing café customers' purchase intention with various attributes.
\end{abstract}

Keywords: coffee shop; purchase intention; healthiness; hygiene; quarantine; ease of app use; multiple linear regression

\section{Introduction}

The coffee shop business has a substantial market size in the foodservice sector. The coffee service business accounts for approximately 48 billion dollars in 2019 sales [1]. Although the coffee market's economic output is sizable, it is highly competitive due to low entry barriers and the fact that customers easily change their loyalty to another brand's café product [2]. Such conditions lead coffee shop business (e.g., Starbucks) managers to implement various marketing strategies (e.g., online software service, green marketing, maintaining sound quality of product, and developing new menu) to accomplish competitive advantage by achieving more efficient resource allocation. Hence, it could be valuable to offer information to coffee shop managers regarding efficient resource allotment for more appropriate business strategies. For the accomplishment of such purpose, purchase intention works as the explained variable of the current study because it not only directly contributes to sales growth, but prior studies indicate it is also a common element in consumer intention research [3-7]. Given its popularity and importance, this study explores the determinants of coffee shop purchase intention.

Food safety could become the domain to make businesses more competitive because people consider the condition of their food to be crucial. Prior literature defines food safety using two elements, healthiness and hygiene, which are associated with the health condition (e.g., obesity, high blood pressure, and foodborne illness) of café customers [8-12]. Despite the essence of the food sector, scholars have insufficiently examined the effects of food safety on building the coffee shop customer intention more. The next domain of 
this research is quarantine. Under coronavirus disease (COVID)-19 conditions, individuals' food consumption patterns changed, and quarantine could play a key role as a determinant of decision making in food service areas because the disease causes undesirable consequences. Because of the risk, COVID-19 is likely to hinder the sales growth of coffee business, and coffee businesses might endeavor to minimize their loss by concentrating on quarantine. However, studies have rarely assessed the effect of quarantine on consumer intention. Another area of this research is the ease of app use. According to Starbucks stories and news [13], the coffee chain's software application is very popular, and consumers purchase products through its online system more and more. Even though the system is popular, studies have rarely shown whether the system brings about buying intention. Considering the technology acceptance model, a widely used theoretical underpinning that links system characteristics and consumer intention and behavior, it could be valuable to identify the association between ease of app use and purchase intention in the café customer sector. Such a test enables this research to contribute to the literature by testing the accountability of the technology acceptance model for the café product purchase intention. The last domain is environmental responsibility. There is a controversy in prior studies whether environmental perception leads consumers to build a purchase intention; it appears varied depending on the business area regarding the causal significance and relationship between variables (e.g., direct and indirect effect on the purchase behavior and intention) $[4,14-16]$. Based on such mixed findings, environmental responsibility becomes the last element for the solution of this question in the context of café customer research. Overall, five attributes are chosen as explanatory elements for purchase intention: healthiness, hygiene, quarantine, ease of app use, and environmental responsibility.

Starbucks is the research domain. According to Statista [17], Starbucks maintained approximately $40 \%$ of the US market share in 2019. Such a market share increases the likelihood of response based on concrete consumer experiences. Moreover, Starbucks performs various marketing strategies (e.g., healthy food offerings, open kitchens for food hygiene, quarantine implementation, provision of mobile ordering systems, and eco-friendly marketing) [18-21]. The popularity in the market and various marketing implementations of Starbucks allow survey participants to respond to the questions more vividly given their concrete experience of café goods and service.

\section{Literature Review and Hypotheses Development}

\subsection{Purchase Intention}

Purchase intention refers to the degree to which a consumer is willing to buy a certain product or service, and purchases play a pivotal role in any business's sales growth and market share $[3,6,22]$. Hence, scholars have investigated purchase intention. For example, Wang and Tsai [23] researched antecedents of purchase intention in the domain of brand management using risk, value, and quality as antecedents; Dehghani and Tumer [24] employed purchase intention as a dependent variable by evaluating the effect of Facebook advertising. Rana and Paul [5] implemented organic food research by selecting purchase intention as the explained attribute, and the study uncovered that health appeared as a significant attribute to account for purchase intention. Hsiao and Chen [7] executed research to account for purchase intention in smartwatch merchandising. Suki [4] also employed purchase intention as the main attribute in researching the effect of green marketing. In a similar vein, Chen and Lee [25] performed research in coffee consumers' domain, aiming to present purchase intention determinants using green related attributes (e.g., green trust, green satisfaction, and ethical bean sourcing). Based on the literature review, many scholars have employed purchase intention as a dependent variable, and it can be inferred that purchase intention is a valuable attribute to investigate. Therefore, purchase intention is employed as the outcome variable in this research. 


\subsection{Food Safety: Healthiness and Hygiene}

Prior studies claim that two food safety areas are healthiness and hygiene [26-29]. Healthiness is related to obesity and high blood pressure caused by high sugar, fat, and calories. Previous studies have documented that hygiene is linked with the cleanliness of food, sanitation, and contamination (e.g., chemical, physical, and microbiological) [8-10,12,30]. Poor hygiene causes food-borne illnesses such as food poisoning $[8,12,27,28]$. Because food safety directly affects individual health conditions, it is an essential consideration by consumers in terms of their decision making $[10,11,31,32]$. In fact, numerous empirical studies illustrate the effect of food safety on consumer decision making. For example, Krystallis and Chryssohoidis [33] documented that food safety positively affects willingness to pay in the context of the organic food market. $\mathrm{Xu}$ and $\mathrm{Lu}$ [10] conversely showed that consumers' willingness to pay and purchase choice is hindered by consumers possessing more food logistic and processing information. It indicates that customers meticulously review safety within food purchase. Rana and Paul [5] found that organic food purchase intention in positively influenced by healthiness using multiple regression analysis. Similarly, Wongprawmas and Canavari [34] explored Thailand consumers implementing choice experiment and found that food safety by labelling positively affects willingness to pay. Moreover, Huang and $\mathrm{Lu}$ [35] revealed a positive association between food healthiness measured by food package color and purchase intention by implementing an experimental study. Kumar and Kapoor [36] demonstrated that labeling, which reflects food safety, is essential for building consumer purchase intentions by investigating Indian market consumers. Based on the literature review, the following research hypotheses are proposed:

H1: Healthiness positively affects purchase intention in coffee services.

H2: Hygiene positively affects purchase intention in coffee services.

\subsection{Quarantine}

The COVID-19 pandemic has changed life patterns and economic conditions, and it affects eating-out behavior by focusing more on takeout consumption [37-39]. In this condition, safety from the infection is regarded as a crucial element because the likelihood of infection grows when engaged in eating and talking situations [40-42]. Under this circumstance, quarantine appeared to be an important issue in the foodservice domain. Even though consumers consider quarantine as a critical element, few studies have researched the effect of quarantine and risk perception toward epidemics on consumer behavior and decision making. Indirectly, empirical studies presented evidence between safety, epidemic perception, and consumer reaction. For example, Khan, Sarwar, and Tan [43] suggest that consumer purchase intention is positively influenced by cosmetic safety. Moreover, Pine and McKercher [44] and Cooper [45] uncovered that tourism intention is negatively affected by the severe acute respiratory syndrome. Regarding COVID-19, Bae and Chang [46] documented a negative effect on behavioral intention of tourism. From the literature review, it implies that consumer decision making is likely to be influenced by quarantine perceptions. However, prior studies have scantly examined the impact of COVID-19 quarantine on the consumer purchase intention. This work thus proposes the following hypothesis:

H3: Quarantine positively affects purchase intention in coffee services.

\subsection{Ease of App Use}

According to the technology acceptance model, ease of use for technology leads consumers to make favorable decisions, and ease of use refers to the degree to which users perceive handling the technology in purchase processes without complexity or difficulty $[47,48]$. This is because complexity in use discourages consumers and builds barriers to accessing certain goods and services, which triggers negative consequence (e.g., switching intention, stress, and anger) [48,49]. Indeed, Starbucks offers a software application system that aims to encourage consumers to purchase more of its products by offering convenience and enhancing accessibility [13]. A vast body of literature has exhibited the 
accountability of ease of technology use for consumer behavior and intention in various domains. For instance, Pai and Huang [50] used the technology acceptance model as a theoretical foundation in the healthcare information system business, and the finding was a positive association between ease of use and intention to use. Lee, Hsieh, and Hsu [51] adopted a technology acceptance model in the context of employee training and e-learning and used ease of use as the main attribute. Lee and Lehto [52] and Chae [53] empirically implemented the exploration for the behavioral characteristics of YouTube users and clothing consumers, respectively, using a technology acceptance model as theoretical underpinning. Moreover, Chu and Lu [54] reported a positive linear relation between attributes derived from the technology acceptance model and online music product purchase intention. In a similar vein, Yadav and Mahara [55] demonstrated a positive association between ease of use and intention to use employing wooden handicrafts market consumers, which they attributed to the fact that customers could reduce their mental energy and effort to access the goods and service via ease of technology use. Hence, the next research hypothesis is proposed as follows:

H4: Ease of app use positively affects purchase intention in coffee services.

\subsection{Environmental Responsibility}

Environmental responsibility is defined as consumer perception of a certain business's eco-friendly management $[16,56,57]$. A vast body of literature asserts that environmental aspects have varied effects on consumer behavior $[4,14,15]$. Namely, certain studies presented the significance of environmental elements on consumer decision making and intention, whereas some studies disclosed the indirect effect of environmental elements on consumer behavior and intention. In detail, Kong, Harun, Sulong, and Lily [58] noted that green practices influence consumer purchase intentions in varied circumstances, depending on the marketing strategy (e.g., labeling, packaging, and corporate image). Suki [4] found that a green image plays an imperative role in determining purchase intention. However, prior literature has also disclosed the indirect effects of eco-friendly perception. As an example, Wu and Chen [15] noted an indirect path appraising the green marketing effect on purchase intention through innovativeness. This finding was validated by Punyatoya [14], showing the path of environmental perception, trust, and purchase intention. Assaker, O'Connor, and El-Haddad [59] offered empirical evidence for the relationship between green image, quality, satisfaction, and loyalty regarding green images' indirect effect on consumer behavior. In a study limited to examining consumer intention in café businesses, Jeong, Jang, Day, and Ha [60] revealed that green perception builds positive attitudes. From the literature review, it can be inferred that the effect of environmental perception is controversial. Given the controversy in diverse domains, the effect of environmental perception on purchase decisions needs elucidation in the context of cafe product consumer research. Concerning the review of the literature, the last research hypothesis is presented as follows:

H5: Environmental responsibility positively affects purchase intention in coffee services.

\section{Method}

\subsection{Research Model and Measurements}

Figure 1 shows the research model. The dependent variable is purchase intention. In addition, this research used five elements as independent variables: healthiness, hygiene, quarantine, ease of app use, and environmental responsibility. This study proposes that the directions of all five variables are positive. 


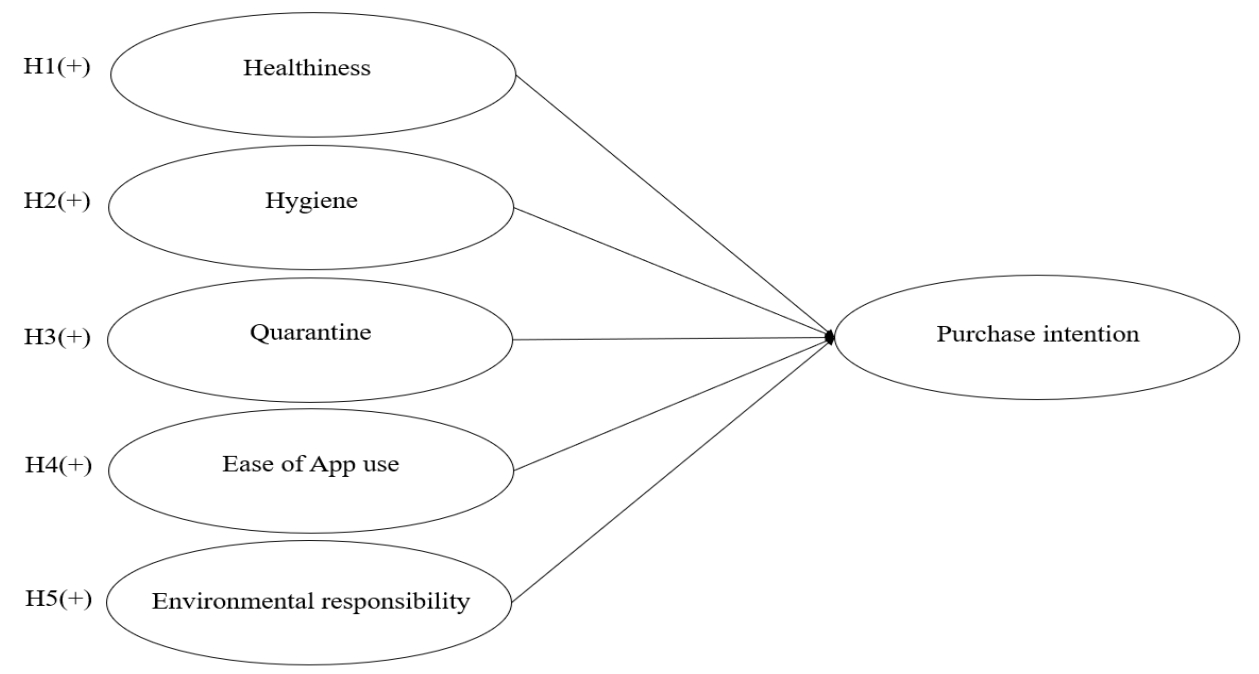

Figure 1. Proposed research hypotheses.

The survey is the main instrument for data collection. The survey contains demographic information questions. The information and measurements are presented as follows: gender $(0=$ male, $1=$ female $)$, age $(1=$ younger than $20,2=20-29$ years old, $3=30-39$ years old, $4=40-49$ years old, $5=50-59$ years old, $6=$ older than 60 years old), employment $(0=$ unemployed, $1=$ employed $)$, weekly use frequency $(1=$ less than 1 time, $2=1-2$ times, $3=3-5$ times, $4=$ more than 5 times), and monthly household income $(1=$ less than $\$ 2000,2=\$ 2000-3999,3=\$ 4000-5999,4=\$ 6000-7999,5=\$ 8000-9999$, $6=$ more than $\$ 10,000)$. This research used a five-point Likert scale $(1=$ strongly disagree, $5=$ strongly agree) to measure the main elements.

The measurement items of purchase intention were employed and revised following the extant literature with its definition being the intention to buy services and goods from a coffee shop $[7,22,23,25]$. Healthiness is defined as how the product is useful in promoting consumer health. The definition of hygiene is how consumers perceive the product in terms of being clean and safe (i.e., sanitation). These two items are also measured by consulting the extant literature $[10,30,33-35,61]$. In addition, the authors consulted foodservice research experts to attain the quarantine measurement items, given the scarce coverage in previous studies to derive the measurement items. Quarantine is defined as how a coffee shop administrates quarantine procedures to protect consumer health against COVID-19. This research defines the ease of app use as how consumers perceive Starbucks' software applications regarding its lack of complexity. Furthermore, environmental responsibility is defined as how consumers construct a positive, eco-friendly image of café businesses. Both ease of app use $[49,50,52,55]$ and environmental responsibility $[14,56,58,59]$ were derived from previous studies. All the attributes are composed of four items.

\subsection{Data Collection and Analysis}

Amazon Mechanical Turk (https:/ / www.mturk.com/ (accessed on 2 February 2021)) was the main instrument for data collection. Previous studies have collected fertile data using Amazon Mechanical Turk and have presented statistically significant inferences [62-64]. Such popularity and quality led this study to employ Amazon Mechanical Turk as its main data collection instrument. Additionally, this study aims to scrutinize American consumers because Starbucks is a representative American corporation and Amazon Mechanical Turk possesses copious American panels for data service. For the data collection, this study offered financial compensation for each survey participant with the commission fee for Amazon Mechanical Turk service. Initially, this research collected 500 observations and deleted 26 observations due to poor response quality (e.g., incomplete response and no demographic information). The validation rate was $94.8 \%$. As a result, 474 observations 
were used for the data analysis. The data collection was carried out between 7 and 10 December 2020.

Initially, frequency analysis to obtain survey participants' demographic information was performed. Then, exploratory factor analysis using varimax rotation was implemented to assess the validity of the measurement. Hair, Anderson, Babin, and Black [65] claim that the factor loading threshold is 0.5 . The significance of exploratory factor analysis was evaluated by Kaiser-Meyer-Olkin (KMO) using 0.7 as the criterion and the significance of Bartlett's $\chi^{2}$ at the $99 \%$ level. This research derived constructs by checking the eigenvalue using 1 as the cutoff value [65]. Cronbach's $\alpha$ was the criteria to test its reliability, and the criterion was 0.7 , considering Hair et al. [65]. Then, the mean and standard deviation (descriptive statistic) were calculated for the main attributes. This research also executed a correlation matrix analysis at the $95 \%$ significance level. To test the hypotheses, we implemented multiple linear regression analyses. Two models are explored to check the robustness of the results. Only five main variables are investigated in the first regression model, and control variables are included in the second regression model. The control variables include gender, age, weekly use frequency, household income, and employment status. The results of hypothesis testing were evaluated regarding consistency in terms of direction and significance. By checking consistency of coefficients, this research attempts to minimize the likelihood of error in estimation and check the potential effect of demographic attribute to account for the dependent variable (e.g., purchase intention).

\section{Results}

\subsection{Sample Profile}

Table 1 illustrates the demographic information of the survey participants. The number of male participants was 289 , while the number of female participants was 185 . Namely, $61 \%$ of survey participants were male. The number of employed individuals was 415 , whereas the number of unemployed individuals was 59. This indicates that most participants are employed. Table 1 also presents the information on age (younger than 20 years old $=4,20-29$ years old $=184,30-39$ years old $=181,40-49$ years old $=60,50-59$ years old $=32$, older than 60 years old $=13$ ). That is, about $75 \%$ of survey participants were between 20 and 39 years old. With regard to the number of observations for monthly household income, the number of observations for less than $\$ 2000$ was $94, \$ 2000-3999$ was $138, \$ 4000-5999$ was $97, \$ 6000-7999$ was $45, \$ 8000-9999$ was 47 , and more than $\$ 10,000$ was 53. Last, Table 1 describes the weekly visit frequency of survey participants (less than 1 visit: 163 ; $1-2$ visits: 192 ; $3-5$ visits: 94 ; and more than 5 visits: 25 ). It shows that approximately $75 \%$ of participants used Starbucks less than 2 times a week.

Table 1. Sample characteristics $(\mathrm{N}=474)$.

\begin{tabular}{ccc}
\hline Item & Frequency & Percentage \\
\hline Male & 289 & 61.0 \\
Female & 185 & 39.0 \\
Younger than 20 years old & 4 & 0.8 \\
20-29 years old & 184 & 38.8 \\
30-39 years old & 181 & 38.2 \\
$40-49$ years old & 60 & 12.7 \\
$50-59$ years old & 32 & 6.8 \\
Older than 60 years old & 13 & 2.7 \\
Employed & 415 & 87.6 \\
Unemployed & 59 & 12.4 \\
Monthly household income & 94 & 19.8 \\
Less than $\$ 2000$ & 138 & 29.1 \\
Between $\$ 2000$ and $\$ 3999$ & 97 & 20.5 \\
Between $\$ 4000$ and $\$ 5999$ & 45 & 9.5 \\
Between $\$ 6000$ and $\$ 7999$ & 47 & 9.9 \\
Between $\$ 8000$ and $\$ 9999$ & & \\
\hline
\end{tabular}


Table 1. Cont.

\begin{tabular}{ccc}
\hline Item & Frequency & Percentage \\
\hline More than $\$ 10,000$ & 53 & 11.2 \\
Weekly visiting frequency & & \\
Less than 1 time & 163 & 34.4 \\
$1 \sim 2$ times & 192 & 40.5 \\
$3 \sim 5$ times & 94 & 19.8 \\
More than 5 times & 25 & 5.3 \\
\hline
\end{tabular}

Note: Gender $(0=$ male, $1=$ female), Age ( $1=$ younger than $20,2=20-29$ years old, $3=30-39$ years old, $4=40-49$ years old, $5=50-59$ years old, $6=$ older than 60 years old $)$, Employment $(0=$ unemployed, $1=$ employed), Weekly use frequency ( $1=$ less than 1 time, $2=1-2$ times, $3=3-5$ times, $4=$ more than 5 times), Monthly household income ( $1=$ less than $\$ 2000,2=\$ 2000-3999,3=\$ 4000-5999,4=\$ 6000-7999,5=\$ 8000-9999$, $6=$ more than $\$ 10,000)$.

\subsection{Exploratory Factor Analysis and Reliability Test Results}

Table 2 presents the results of exploratory factor analysis and reliability tests using Cronbach's alpha. The results of exploratory factor analysis were significant $(\mathrm{KMO}=0.932$, Bartlett's test of sphericity $\left.\chi^{2}=7160.678(p<0.01)\right)$. The validity of the overall items is acceptable, given the factor loading values, which are greater than 0.5. Given the eigenvalues, six factors are derived, and all constructs are composed of four items. The six elements' reliability is appropriate because Cronbach's $\alpha$ values are greater than 0.7 . Consequently, this research attained six factors: healthiness, quarantine, ease of app use, purchase intention, hygiene, and environmental responsibility.

Table 2. Illustration of the results of exploratory factor analysis and reliability test $(\mathrm{N}=474)$.

\begin{tabular}{|c|c|c|c|}
\hline Construct $(\alpha)$ & Item & Factor Loading & $\begin{array}{l}\text { Eigen Value } \\
\text { (Variance } \% \text { ) }\end{array}$ \\
\hline \multirow{4}{*}{$\begin{array}{l}\text { Healthiness } \\
(\alpha=0.891)\end{array}$} & Starbucks products are healthy. & 0.825 & \multirow{4}{*}{$\begin{array}{c}10.089 \\
(42.037)\end{array}$} \\
\hline & Starbucks products improve my health condition. & 0.813 & \\
\hline & Starbucks offers health concerning products. & 0.804 & \\
\hline & Starbucks products contain low calories. & 0.819 & \\
\hline \multirow{4}{*}{$\begin{array}{l}\text { Quarantine } \\
(\alpha=0.872)\end{array}$} & Starbucks is good at COVID 19 quarantine. & 0.697 & \multirow{4}{*}{$\begin{array}{c}2.501 \\
(10.422)\end{array}$} \\
\hline & Starbucks keeps COVID 19 quarantine well. & 0.797 & \\
\hline & Starbucks employees perform well for COVID 19 quarantine. & 0.619 & \\
\hline & COVID 19 quarantine is well implemented at Starbucks. & 0.770 & \\
\hline \multirow{4}{*}{$\begin{array}{l}\text { Ease of app use } \\
\qquad(\alpha=0.857)\end{array}$} & The Starbucks app is easy to use. & 0.778 & \multirow{4}{*}{$\begin{array}{c}1.401 \\
(5.836)\end{array}$} \\
\hline & It is not complex to use the Starbucks app. & 0.746 & \\
\hline & Starbucks provides an easy app system to use. & 0.803 & \\
\hline & It is straightforward to use the Starbucks app. & 0.749 & \\
\hline \multirow{4}{*}{$\begin{array}{l}\text { Purchase } \\
\text { intention } \\
(\alpha=0.872)\end{array}$} & I am willing to pay for Starbucks products. & 0.800 & \multirow{4}{*}{$\begin{array}{c}1.367 \\
(5.695)\end{array}$} \\
\hline & Starbucks products deserve to pay. & 0.604 & \\
\hline & I am going to pay for Starbucks goods. & 0.786 & \\
\hline & I will buy Starbucks products. & 0.739 & \\
\hline \multirow{4}{*}{$\begin{array}{l}\text { Hygiene } \\
(\alpha=0.858)\end{array}$} & Starbucks products are hygienic. & 0.711 & \multirow{4}{*}{$\begin{array}{l}1.113 \\
(4.639)\end{array}$} \\
\hline & Starbucks products are clean to consume. & 0.786 & \\
\hline & Sanitation of Starbucks goods is well managed. & 0.605 & \\
\hline & Starbucks food is clean and hygienic to consume. & 0.766 & \\
\hline \multirow{4}{*}{$\begin{array}{l}\text { Environmental } \\
\text { responsibility } \\
\quad(\alpha=0.857)\end{array}$} & Starbucks uses recycled materials for goods. & 0.819 & \multirow{4}{*}{$\begin{array}{l}1.034 \\
(4.310)\end{array}$} \\
\hline & Starbucks is eco-friendly. & 0.591 & \\
\hline & Starbucks offers environmental goods. & 0.743 & \\
\hline & Starbucks products protect the environment. & 0.603 & \\
\hline
\end{tabular}

Note: Kaiser-Meyer-Olkin $(\mathrm{KMO})$ Measure $=0.932$, Bartlett's Test of Sphericity $\chi^{2}=7160.678(p<0.01)$, total variance explained: $72.939 \%$.

\subsection{Correlation Matrix}

Table 3 is the correlation matrix and descriptive statistics of the main attributes. The mean value of binary purchase intention is 0.869 , and its standard deviation is 0.337 , while the mean value of purchase intention is 3.856 , and its standard deviation is 0.826 . 
Table 3 also describes the descriptive statistics of healthiness (mean $=3.457, \mathrm{SD}=0.961$ ), hygiene (mean $=4.040, \mathrm{SD}=0.728)$, quarantine (mean $=3.808, \mathrm{SD}=0.782)$, ease of app use (mean $=4.018, \mathrm{SD}=0.747)$, and environmental responsibility $($ mean $=3.724, \mathrm{SD}=0.841)$. In detail, Starbucks consumers are relatively skeptical about healthiness, while hygiene and ease of app use are perceived as quite positive manners at Starbucks. Purchase intention also positively correlates with healthiness $(r=0.484)$, hygiene $(r=0.570)$, quarantine $(r=0.585)$, ease of app use $(r=0.506)$, and environmental responsibility $(r=0.506)$, meaning that five attributes could positively affect purchase intention. Table 3 depicts the healthiness correlation coefficients with hygiene $(r=0.346)$, quarantine $(r=0.400)$, ease of app use $(r=0.252)$, and environmental responsibility $(r=0.575)$. Moreover, hygiene positively correlates with quarantine $(r=0.626)$ and environmental responsibility $(r=0.505)$. Ease of app shows positive correlation with quarantine $(\mathrm{r}=0.508)$ and environmental responsibility $(\mathrm{r}=0.451)$. All in all, health-related attributes including healthiness, hygiene, and quarantine are closely related to each other, and ease of app use could be linked with better quarantine and more environmental measures by minimizing interpersonal contact and waste amount, respectively.

Table 3. Correlation matrix $(\mathrm{N}=474)$.

\begin{tabular}{|c|c|c|c|c|c|c|c|}
\hline & Mean & SD & 1 & 2 & 3 & 4 & 5 \\
\hline 1. Purchase intention & 3.856 & 0.826 & 1 & & & & \\
\hline 2.Healthiness & 3.246 & 1.027 & 0.484 * & 1 & & & \\
\hline 3. Hygiene & 4.040 & 0.728 & 0.570 * & $0.364 *$ & 1 & & \\
\hline 4. Quarantine & 3.808 & 0.782 & $0.585^{*}$ & $0.400 *$ & $0.626 *$ & 1 & \\
\hline 5. Ease of app use & 4.018 & 0.747 & $0.506^{*}$ & $0.252 *$ & $0.563 *$ & $0.508 *$ & 1 \\
\hline 6. Environmental responsibility & 3.724 & 0.841 & $0.506^{*}$ & 0.573 * & $0.505^{*}$ & 0.579 * & $0.451 *$ \\
\hline
\end{tabular}

Note: SD stands for standard deviation, ${ }^{*} p<0.05$.

\subsection{Results of Hypotheses Testing}

Table 4 illustrates the results of the multiple linear regression analysis. The dependent variable is purchase intention. Model 1 and Model 2 are statistically significant, given the significance of F-values $(p<0.05)$. The results show that healthiness $(\beta=0.196$, $p<0.05)$, hygiene $(\beta=0.232, p<0.05)$, quarantine $(\beta=0.255, p<0.05)$, and ease of app use $(\beta=0.210, p<0.05)$ are positively associated with purchase intention. It suggests that customers pay more for Starbucks goods and service if they perceive better healthiness, hygiene, quarantine, and more ease of use of the mobile software application. The results also present a significant effect of weekly use frequency on purchase intention $(\beta=0.113$, $p<0.05$ ), whereas other control variables are not significant. However, environmental responsibility appeared to be a nonsignificant attribute for purchase intention. All the hypotheses are supported other than hypothesis 5 . It notes that environmental responsibility does not cause purchase intention directly. Figure 2 describes the results of hypotheses testing. 
Table 4. Results of multiple linear regression $(\mathrm{N}=474)$.

\begin{tabular}{|c|c|c|c|}
\hline Variable & $\begin{array}{c}\text { Model1 } \\
\beta(t \text {-Value })\end{array}$ & $\begin{array}{c}\text { Model2 } \\
\beta \text { ( } t \text {-Value) }\end{array}$ & Results \\
\hline Constant & $0.328(1.87)$ & $0.400(1.85)$ & \\
\hline Healthiness & $0.196(6.02) *$ & $0.143(4.09) *$ & H1 Supported \\
\hline Hygiene & $0.232(4.43)$ * & $0.249(4.79) *$ & H2 Supported \\
\hline Quarantine & $0.255(5.18) *$ & $0.236(4.75) *$ & H3 Supported \\
\hline Ease of app use & $0.210(4.57)$ * & $0.201(4.40) *$ & H4 Supported \\
\hline Environmental responsibility & $0.035(0.77)$ & $0.032(0.17)$ & H5 Not supported \\
\hline Gender & & $0.009(0.75)$ & \\
\hline Employment & & $0.063(0.17)$ & \\
\hline Weekly using frequency & & $0.113(3.18) *$ & \\
\hline Monthly household income & & $0.005(0.28)$ & \\
\hline Age & & $-0.049(-1.81)$ & \\
\hline F-value & $90.55 *$ & $48.01 *$ & \\
\hline $\mathrm{R}^{2}$ & 0.4917 & 0.4691 & \\
\hline Adjusted $\mathrm{R}^{2}$ & 0.4893 & 0.4588 & \\
\hline
\end{tabular}

Note: Dependent variable: Purchase intention, ${ }^{*} p<0.05$.

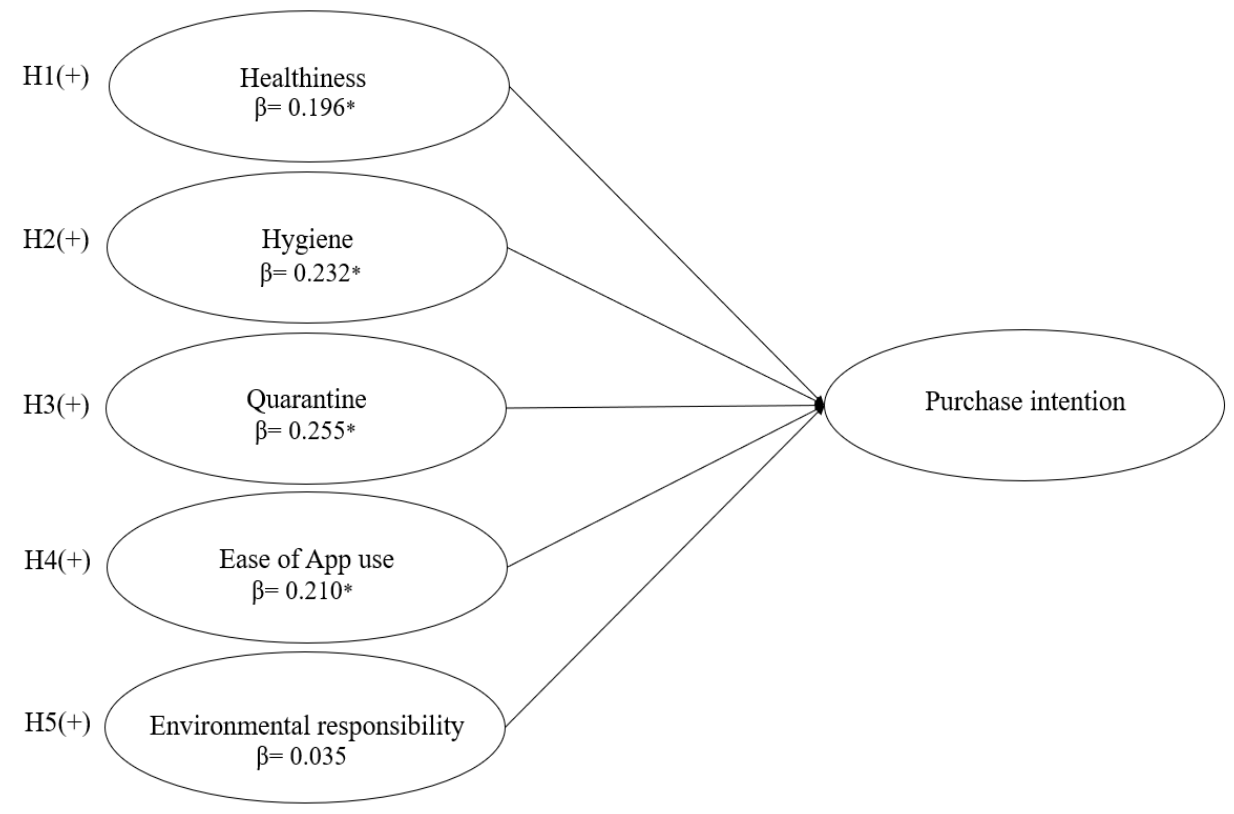

Figure 2. Results of hypotheses testing. Note: ${ }^{*} p<0.05$.

\section{Discussion and Conclusions}

\subsection{Interpretation of the Results}

This research aims to inspect the antecedents of purchase intention in the context of café businesses. Starbucks was selected as the area of study because the brand possesses the largest market share. Five attributes were adopted as independent variables: healthiness, hygiene, quarantine, ease of app use, and environmental responsibility. By using a survey instrument, this study tested accountability for purchase intention. It was found that purchase intention is positively affected by healthiness, hygiene, quarantine, and ease of app use. Namely, Starbucks sales growth is likely to be accomplished by healthiness, hygiene, quarantine, and ease of app use. Hence, the results suggest that offering a healthy menu, safe atmosphere for hygiene and quarantine, and providing an easy mobile system to purchase products are the avenues to accomplish sales growth. Given the magnitude of coefficients, healthiness was the most influential. Additionally, hygiene and quarantine are more imperative attributes to promote Starbucks product purchase than ease of app use and healthiness. The results also indicate that ease of app use is a more influential 
attribute to purchase intention as compared to healthiness. Considering mean and standard deviation of constructs, it is disclosed that Starbucks consumers are the most skeptical of the product's healthiness, which could be due to the high levels of caffeine, calories, and sugar in certain products. However, Starbucks consumers evaluated the ease of app use and hygiene in an entirely positive manner.

\subsection{Explanation for the Hypotheses Testing}

This study used five candidates to account for purchase intentions, and the results revealed that four attributes (e.g., healthiness, hygiene, quarantine, and ease of app use) were significant to account for purchase intention. However, this research showed that environmental responsibility worked as a nonsignificant attribute for purchase intention, indicating that the environmental element is not critical for sales growth in the context of café businesses. It is possible that either an indirect path toward a certain attribute (e.g., trust, risk, and value) for the environmental element or other specific green areas (e.g., labeling, organic sourcing, or packaging) might determine purchase intention significantly in the coffee shop business domain, as previous research has addressed [58-61,66]. This implies that more in-depth investigation of the environmental responsibility is necessary to consider more diverse paths and variables.

\subsection{Theoretical Implications}

This paper theoretically contributes to the literature in the domain of café business service. Despite its abundance in food related research domain, scholars have rarely studied the link between purchase intentions and coffee service businesses' food safety. Indeed, two attributes (e.g., healthiness and hygiene) related to food safety exerted a significant impact on purchase intention. As previous research has addressed, food quality appeared as an imperative element in consumer behavior, which might be due to the fact that healthiness has become more valued aspect in consumer perception [67-74]. Such a finding could make the area of coffee shop business research more fruitful by elaborating the food safety elements (e.g., hygiene and healthiness) as well as validating the findings from extant literature [5,10,34-36,75-79]. Although the COVID-19 pandemic and its quarantine are influential in individual life, previous studies have rarely researched the association between quarantine and consumer behavior and intention despite of it being regarded as essential social issue. By showing the relationship between quarantine and purchase intention, this research outcome fills the research gap and validates the argument that COVID-19 has changed the consumption patterns, as prior literature addressed [37,38,70,79]. Next, this research's findings considering ease of app use presented external validity by utilizing the extant literature. The results would be valuable because technology is common and popular in hospitality and tourism sector $[49,50,52,55,75-77,80]$. Namely, this study expanded the accountability of technology acceptance model regarding ease of use in café business domain's software application service. Extant literature documented controversial results in terms of accountability significance for the purchase intention regarding ease of use. In detail, scholars disclosed that ease of use significantly affected purchase intention in Indonesian consumer to consumer (C2C) transaction technology and Taiwan online shopping customers $[75,76]$. In contrast, ease of use exerted a non-significant impact on purchase intention in the domain of online travel booking [80]. Such mixed findings suggest that the ease of use's explanatory power is varied depending on the research context. Regarding its controversy, this study could contribute to the literature by demonstrating significant impact of ease of use in the coffee shop customer research domain. Furthermore, this work clarifies the link between environmental responsibility in prior studies [81] and purchase intention in the café business. Even though the results appeared to be non-significant, elucidation considering the effect of environmental responsibility on purchase intention appeared in the café business domain. To be specific, Jeong et al. [60] was limited because the study only assessed the effect of eco-friendliness on attitude rather than intention. 
Given the void, this study tested the effect of environmental responsibility on purchase intention and found non-significant connection between two attributes.

\subsection{Practical Implication}

There are practical implications. The results of this research could inform Starbucks managers and help establish more economical marketing strategies. Coffee shop managers might need to allocate their resources to develop a healthy menu (e.g., fruits and vegetables, decaffeinated beverages, and low-calorie products). Moreover, Starbucks managers might need to concentrate on hygiene-related aspects, such as open kitchens and maintaining clean kitchen conditions with employee training. Starbucks managers might also consider preparing quarantine-related equipment and items (e.g., thermometers, hand sanitizer, emphasizing wearing mask in stores to both employee and customers, and employee training in quarantine procedures) [82]. Additionally, Starbucks managers might allot their capabilities to develop an easier online ordering system and smartphone application system regarding the importance of technological infrastructure for competitiveness in hospitality [83,84]. These elements (i.e., healthiness, hygiene, quarantine, and ease of app use) could help the coffee service businesses increase sales. Furthermore, this study could inform Starbucks managers to decide the priority of marketing effort planning. The results suggested that hygiene and quarantine are more crucial attributes than ease of app use to accomplish more sales growth. Afterward, ease of app use could also become the more efficient area for resource allocation than developing a healthy menu in Starbucks business area. Indeed, Starbucks managers could attain guidance for the resource management by considering the information. For the environmental aspect, Starbucks managers might implement their decision making more carefully, although it will not increase sales directly. This is because building an environmental image might produce indirect effects or synergistic effects with other business strategies in Starbucks's business domain.

\subsection{Limitations and Suggestions for Future Research}

This research has limitations. Above all, this work is limited to examining this attribute. Hence, future research needs to perform this research using more specific environmental responsibility and quarantine protocols. By doing so, future research could produce more elaborated practical implications for the management for both environmental responsibility and quarantine. In addition, indirect paths considering environmental responsibility mediators could become an avenue to produce more valuable results. Moreover, this study is limited to the American market. Otherwise, regarding environmental responsibility as moderator could become another avenue to understand café customers more. Moreover, future research should also regard more diverse attributes (e.g., consumers' attitudes toward the product (e.g., taste), motivations or convenience factors) to understand consumer intention. Such an additional attribute consideration will lead future researchers to understand Starbucks's customer more. Regarding Starbucks as a multinational business, future research needs to investigate consumer behavior using different geographical markets. Future studies should also consider more various attributes as control variables such as existing attitude, awareness, and preference, which would allow future studies to attain more statistically robust estimations.

Author Contributions: Conceptualization, W.S.L. and M.S.; Data curation, J.S. and J.M.; Formal analysis, J.S. and J.M.; Methodology, J.M. and M.S.; Supervision, W.S.L. and M.S.; Writing - original draft, W.S.L. and J.S. All authors have read and agreed to the published version of the manuscript.

Funding: This work was supported by the Ministry of Education of the Republic of Korea and the National Research Foundation of Korea (NRF-2019S1A3A2098438).

Conflicts of Interest: The authors declare no conflict of interest. 


\section{References}

1. World Coffee Portal. Major Chains Driving US Coffee Shop Growth-But Overall Market Slows. 2019. Available online: https: / / www.worldcoffeeportal.Com/Latest/News/2019/Major-Chains-Driving-US-Coffee-Shop-Growth-\%E2\%80\%93-But-O (accessed on 28 December 2020).

2. Ibis World. Coffee \& Snack Shops Industry in the US. 2020. Available online: https://www.ibisworld.com/united-states/marketResearch-reports/Coffee-Snack-Shops-Industry/ (accessed on 28 December 2020).

3. Gunawan, D.D.; Huarng, K.-H. Viral effects of social network and media on consumers' purchase intention. J. Bus. Res. 2015, 68, 2237-2241. [CrossRef]

4. Suki, N.M. Green product purchase intention: Impact of green brands, attitude, and knowledge. Br. Food J. 2016, 118, 2893-2910. [CrossRef]

5. Rana, J.; Paul, J. Consumer behavior and purchase intention for organic food: A review and research agenda. J. Retail. Consum. Serv. 2017, 38, 157-165. [CrossRef]

6. Alalwan, A.A. Investigating the impact of social media advertising features on customer purchase intention. Int. J. Inf. Manag. 2018, 42, 65-77. [CrossRef]

7. Hsiao, K.-L.; Chen, C.-C. What drives smartwatch purchase intention? Perspectives from hardware, software, design, and value. Telematics Informatics 2018, 35, 103-113. [CrossRef]

8. Redmond, E.C.; Griffith, C.J. Consumer Food Handling in the Home: A Review of Food Safety Studies. J. Food Prot. 2003, 66, 130-161. [CrossRef]

9. Pang, F.; Toh, P.S. Hawker food industry: Food safety/public health strategies in Malaysia. Nutr. Food Sci. 2008, 38, 41-51. [CrossRef]

10. $\mathrm{Xu}, \mathrm{L} . ; \mathrm{Wu}, \mathrm{L}$. Food safety and consumer willingness to pay for certified traceable food in China. J. Sci. Food Agric. 2010, 90, 1368-1373. [CrossRef] [PubMed]

11. Ergönül, B. Consumer awareness and perception to food safety: A consumer analysis. Food Control. 2013, 32, 461-471. [CrossRef]

12. Liu, A.; Niyongira, R. Chinese consumers food purchasing behaviors and awareness of food safety. Food Control. 2017, 79, 185-191. [CrossRef]

13. Starbucks Stories and News. Starbucks Backs Restaurant Tech Company in Creation of End-to-End Digital Platform. 2020. Available online: https:/ / stories.starbucks.com/press/2019/Starbucks-Backs-Restaurant-Tech-Company-in-Creation-of-Endto-End-Digital-Platform-for-Restaurant-Industry / (accessed on 28 December 2020).

14. Punyatoya, P. Linking Environmental Awareness and Perceived Brand Eco-friendliness to Brand Trust and Purchase Intention. Glob. Bus. Rev. 2014, 15, 279-289. [CrossRef]

15. Wu, S.-I.; Chen, Y.-J. The Impact of Green Marketing and Perceived Innovation on Purchase Intention for Green Products. Int. J. Mark. Stud. 2014, 6, 81. [CrossRef]

16. Prakash, G.; Pathak, P. Intention to buy eco-friendly packaged products among young consumers of India: A study on developing nation. J. Clean. Prod. 2017, 141, 385-393. [CrossRef]

17. Statista. Market Share of Selected Leading Coffee Chains in the United States as of October 2019, by Number of Outlets. 2020. Available online: https:/ / www.statista.com/statistics/250166/Market-Share-of-Major-Us-Coffee-Shops / (accessed on 28 December 2020).

18. Starbucks. Global Social Impact. 2019. Available online: https://www.starbucks.com/responsibility/Global-Report (accessed on 28 December 2020).

19. ABC News. Starbucks Announces New Operation Plans, Changes to Employee Pay. 2020. Available online: https://stories. starbucks.com/press/2020/Navigating-through-Covid-19/ (accessed on 29 December 2020).

20. Starbucks Stories and News. Health and Wellness. 2020. Available online: https://stories.starbucks.com/stories/HealthWellness / (accessed on 29 December 2020).

21. Starbucks Stories and News. Starbucks Playbook for Navigating COVID-19. 2020. Available online: https://stories.starbucks. com/press/2020/Navigating-through-Covid-19/ (accessed on 29 December 2020).

22. Sreen, N.; Purbey, S.; Sadarangani, P. Impact of culture, behavior and gender on green purchase intention. J. Retail. Consum. Serv. 2018, 41, 177-189. [CrossRef]

23. Wang, Y.; Tsai, C. The Relationship Between Brand Image and Purchase Intention: Evidence from Award Winning Mutual Funds. Int. J. Bus. Fin. Res. 2014, 8, 27-40.

24. Dehghani, M.; Tumer, M. A research on effectiveness of Facebook advertising on enhancing purchase intention of consumers. Comput. Hum. Behav. 2015, 49, 597-600. [CrossRef]

25. Chen, M.-F.; Lee, C.-L. The impacts of green claims on coffee consumers' purchase intention. Br. Food J. 2015, 117, 195-209. [CrossRef]

26. Shalaby, A.R. Significance of biogenic amines to food safety and human health. Food Res. Int. 1996, 29, 675-690. [CrossRef]

27. Henson, S.; Caswell, J. Food safety regulation: An overview of contemporary issues. Food Policy 1999, 24, 589-603. [CrossRef]

28. Yeung, R.M.; Morris, J. Food safety risk. Br. Food J. 2001, 103, 170-187. [CrossRef]

29. Carvalho, F.P. Pesticides, environment, and food safety. Food Energy Secur. 2017, 6, 48-60. [CrossRef]

30. Srey, S.; Jahid, I.K.; Ha, S.-D. Biofilm formation in food industries: A food safety concern. Food Control. 2013, 31, 572-585. [CrossRef] 
31. Michaelidou, N.; Hassan, L.M. The role of health consciousness, food safety concern and ethical identity on attitudes and intentions towards organic food. Int. J. Consum. Stud. 2008, 32, 163-170. [CrossRef]

32. Martirosyan, A.; Schneider, Y.-J. Engineered Nanomaterials in Food: Implications for Food Safety and Consumer Health. Int. J. Environ. Res. Public Health 2014, 11, 5720-5750. [CrossRef] [PubMed]

33. Krystallis, A.; Chryssohoidis, G. Consumers' willingness to pay for organic food. Br. Food J. 2005, 107, 320-343. [CrossRef]

34. Wongprawmas, R.; Canavari, M. Consumers' willingness-to-pay for food safety labels in an emerging market: The case of fresh produce in Thailand. Food Policy 2017, 69, 25-34. [CrossRef]

35. Huang, L.; Lu, J. The Impact of Package Color and the Nutrition Content Labels on the Perception of Food Healthiness and Purchase Intention. J. Food Prod. Mark. 2016, 22, 191-218. [CrossRef]

36. Kumar, N.; Kapoor, S. Do labels influence purchase decisions of food products? Study of young consumers of an emerging market. Br. Food J. 2017, 119, 218-229. [CrossRef]

37. Roe, B.; Bender, K.; Qi, D. The Impact of COVID-19 on Consumer Food Waste. App. Econ. Pers. Pol. 2020, 1-11. [CrossRef]

38. Salem, M.; Nor, K. The Effect of COVID-19 on Consumer Behaviour in Saudi Arabia: Switching from Brick and Mortar Stores to E-Commerce. Int. J. Sci. Tech. Res. 2020, 9, 15-28.

39. Sheth, J. Impact of Covid-19 on consumer behavior: Will the old habits return or die? J. Bus. Res. 2020, 117, 280-283. [CrossRef]

40. Ben-Hassen, T.; El-Bilali, H.; Allahyari, M.S. Impact of COVID-19 on Food Behavior and Consumption in Qatar. Sustainability 2020, 12, 6973. [CrossRef]

41. Donthu, N.; Gustafsson, A. Effects of COVID-19 on business and research. J. Bus. Res. 2020, 117, 284-289. [CrossRef]

42. Min, S.; Xiang, C.; Zhang, X.-H. Impacts of the COVID-19 pandemic on consumers' food safety knowledge and behavior in China. J. Integr. Agric. 2020, 19, 2926-2936. [CrossRef]

43. Khan, N.; Sarwar, A.; Tan, B.C. Determinants of purchase intention of halal cosmetic products among Generation Y consumers. J. Islam. Mark. 2020, 1-21. [CrossRef]

44. Pine, R.; McKercher, B. The impact of SARS on Hong Kong's tourism industry. Int. J. Contemp. Hosp. Manag. 2004, 16, 139-143. [CrossRef]

45. Cooper, M. Japanese Tourism and the SARS Epidemic of 2003. J. Travel Tour. Mark. 2005, 19, 117-131. [CrossRef]

46. Bae, S.Y.; Chang, P.-J. The effect of coronavirus disease-19 (COVID-19) risk perception on behavioural intention towards 'untact' tourism in South Korea during the first wave of the pandemic (March 2020). Curr. Issues Tour. 2020, 1-19. [CrossRef]

47. Lee, Y.; Kozar, K.A.; Larsen, K.R.T. The Technology Acceptance Model: Past, Present, and Future. Commun. Assoc. Inf. Syst. 2003, 12, 50. [CrossRef]

48. King, W.R.; He, J. A meta-analysis of the technology acceptance model. Inf. Manag. 2006, 43, 740-755. [CrossRef]

49. Surendran, P. Technology Acceptance Model: A Survey of Literature. Int. J. Bus. Soc. Res. 2012, 2, 175-178.

50. Pai, F.-Y.; Huang, K.-I. Applying the Technology Acceptance Model to the introduction of healthcare information systems. Technol. Forecast. Soc. Chang. 2011, 78, 650-660. [CrossRef]

51. Lee, Y.; Hsieh, Y.; Hsu, C. Adding Innovation Diffusion Theory to the Technology Acceptance Model: Supporting employees' Intentions to Use E-Learning Systems. J. Edu. Tech. Soc. 2011, 14, 124-137.

52. Lee, D.Y.; Lehto, M.R. User acceptance of YouTube for procedural learning: An extension of the Technology Acceptance Model. Comput. Educ. 2013, 61, 193-208. [CrossRef]

53. Chae, J.M. The Effect of Mobile Fashion Shopping Characteristics on Consumer's Purchase Intention-Applying the Technology Acceptance Model. Fash. Text. Res. J. 2016, 18, 38-47. [CrossRef]

54. Chu, C.; Lu, H. Factors influencing online music purchase intention in Taiwan. Internet Res. 2007, 17, 139-155. [CrossRef]

55. Yadav, R.; Mahara, T. An Empirical Study of Consumers Intention to Purchase Wooden Handicraft Items Online: Using Extended Technology Acceptance Model. Glob. Bus. Rev. 2017, 20, 479-497. [CrossRef]

56. Jeong, M.-H.; Chae, I.-S. A survey of eco-foodservice perception and satisfaction of elementary school parents in Jeju. J. Nutr. Health 2015, 48, 105-112. [CrossRef]

57. Sundar, A.; Kellaris, J.J. How Logo Colors Influence Shoppers' Judgments of Retailer Ethicality: The Mediating Role of Perceived Eco-Friendliness. J. Bus. Ethics 2015, 146, 685-701. [CrossRef]

58. Kong, W.; Harun, A.; Sulong, R.S.; Lily, J. The Influence of consumers' Perception of Green Products on Green Purchase Intention. Int. J. Asi. Soc. Sci. 2014, 4, 924-939.

59. Assaker, G.; O'Connor, P.; El-Haddad, R. Examining an integrated model of green image, perceived quality, satisfaction, trust, and loyalty in upscale hotels. J. Hosp. Mark. Manag. 2020, 29, 934-955. [CrossRef]

60. Jeong, E.; Jang, S. (Shawn); Day, J.; Ha, S. The impact of eco-friendly practices on green image and customer attitudes: An investigation in a café setting. Int. J. Hosp. Manag. 2014, 41, 10-20. [CrossRef]

61. Angulo, A.M.; Gil, J.M. Risk perception and consumer willingness to pay for certified beef in Spain. Food Qual. Prefer. 2007, 18, 1106-1117. [CrossRef]

62. Shi, X. (Crystal); Gordon, S.E. Organizational support versus supervisor support: The impact on hospitality managers' psychological contract and work engagement. Int. J. Hosp. Manag. 2020, 87, 102374. [CrossRef]

63. Im, J.; Qu, H. Drivers and resources of customer co-creation: A scenario-based case in the restaurant industry. Int. J. Hosp. Manag. 2017, 64, 31-40. [CrossRef]

64. Da Tasci, A. Consumer demand for sustainability benchmarks in tourism and hospitality. Tour. Rev. 2017, 72, 375-391. [CrossRef] 
65. Hair, J.; Anderson, R.; Babin, B.; Black, W. Multivariate Data Analysis: A Global Perspective; Pearson: Upper Saddle River, NJ, USA, 2010; Volume 7.

66. Ali, F.; Ciftci, O.; Nanu, L.; Cobanoglu, C.; Ryu, K. Response Rates In Hospitality Research: An Overview of Current Practice and Suggestions For Future Research. Cornell Hosp. Q. 2020, 62, 105-120. [CrossRef]

67. Kim, K.-S.; Lee, T.J.; Ryu, K. Alternative healthy food choice for tourists: Developing Buddhist temple cuisine. Int. J. Tour. Res. 2018, 20, 267-276. [CrossRef]

68. Ali, F.; Harris, K.J.; Ryu, K. Consumers' return intentions towards a restaurant with foodborne illness outbreaks: Differences across restaurant type and consumers' dining frequency. Food Control. 2019, 98, 424-430. [CrossRef]

69. Kim, H.J.; Park, J.; Kim, M.-J.; Ryu, K. Does perceived restaurant food healthiness matter? Its influence on value, satisfaction and revisit intentions in restaurant operations in South Korea. Int. J. Hosp. Manag. 2013, 33, 397-405. [CrossRef]

70. Naeem, M. Do social media platforms develop consumer panic buying during the fear of Covid-19 pandemic. J. Retail. Consum. Serv. 2021, 58, 102226. [CrossRef]

71. Ryu, K.; Roy, P.A.; Kim, H. (Lina); Ryu, H.B. The resident participation in endogenous rural tourism projects: A case study of Kumbalangi in Kerala, India. J. Travel Tour. Mark. 2019, 37, 1-14. [CrossRef]

72. Wang, J.; Yue, H. Food safety pre-warning system based on data mining for a sustainable food supply chain. Food Control. 2017, 73, 223-229. [CrossRef]

73. Harris, K.J.; Ali, F.; Ryu, K. Foodborne illness outbreaks in restaurants and patrons' propensity to return. Int. J. Contemp. Hosp. Manag. 2018, 30, 1273-1292. [CrossRef]

74. Han, J.-S.; Lee, T.J.; Ryu, K. The promotion of health tourism products for domestic tourists. Int. J. Tour. Res. 2018, 20, 137-146. [CrossRef]

75. Moslehpour, M.; Van Kien, P.; Wong, W.K.; Bilgiçli, I. e-Purchase Intention of Taiwanese Consumers: Sustainable Mediation of Perceived Usefulness and Perceived Ease of Use. Sustainability 2018, 10, 234. [CrossRef]

76. Dachyar, M.; Banjarnahor, L. Factors influencing purchase intention towards consumer-to-consumer e-commerce. Intang. Cap. 2017, 13, 948-970. [CrossRef]

77. Olya, H.; Jung, T.H.; Dieck, M.C.T.; Ryu, K. Engaging visitors of science festivals using augmented reality: Asymmetrical modelling. Int. J. Contemp. Hosp. Manag. 2020, 32, 769-796. [CrossRef]

78. Ryu, K.; Zhong, Y. (Grace). Antecedents and Consequences of Customers' Menu Choice in an Authentic Chinese Restaurant Context. J. Hosp. Mark. Manag. 2012, 21, 852-871. [CrossRef]

79. Ali, F.; Dogan, S.; Amin, M.; Hussain, K.; Ryu, K. Brand anthropomorphism, love and defense: Does attitude towards social distancing matter? Serv. Ind. J. 2021, 37, 1-26. [CrossRef]

80. Yip, W.; Mo, W. An investigation of purchase intention of using mobile Apps for online traveling and booking service. International. J. Inno. Mgt. Tech. 2020, 11, 46-50. [CrossRef]

81. Xu, S.; Kim, H.J.; Liang, M.; Ryu, K. Interrelationships between tourist involvement, tourist experience, and environmentally responsible behavior: A case study of Nansha Wetland Park, China. J. Travel Tour. Mark. 2018, 35, 856-868. [CrossRef]

82. Nisar, Q.A.; Haider, S.; Ali, F.; Naz, S.; Ryu, K. Depletion of psychological, financial, and social resources in the hospitality sector during the pandemic. Int. J. Hosp. Manag. 2021, 93, 102794. [CrossRef]

83. Liu, W.; Ji, R.; Nian, C. (Peter); Ryu, K. Identifying the Types and Impact of Service Provider's Responses to Online Negative Reviews in the Sharing Economy: Evidence from B \& Bs in China. Sustainability 2020, 12, 2285. [CrossRef]

84. Ongsakul, V.; Ali, F.; Wu, C.; Duan, Y.; Cobanoglu, C.; Ryu, K. Hotel website quality, performance, telepresence and behavioral intentions. Tour. Rev. 2020,1-21. [CrossRef] 